\title{
Immunomodulating effects of Phlebotomine saliva in Leishmania infection: Review
}

\author{
Ivan Brito Feitosa ${ }^{\bowtie}$, Wesley Roberto de Aguida $^{2}$ \& Carolina Bioni Garcia Teles ${ }^{3}$
}

1. Institute of Biophysics Carlos Chagas Filho - UFRJ/Fundação Oswaldo Cruz, Fiocruz - RO. 2. Fundação Oswaldo Cruz, Fiocruz Noroeste. 3. Instituto Nacional de Epidemiologia na Amazônia Ocidental - EpIAmO.

\section{EntomoBrasilis 11 (3): 156-161 (2018)}

Abstract. The recognized action of some proteins present in the saliva of the phlebotomine dipteran vectors of Leishmaniasis, as modulators of the hemostatic, inflammatory and immune responses during the colonization of the protozoan in the host organism, created the expectation of formulating a vaccine against this disease. The present study aimed to provide an overview about researchs that deals with the role of phlebotomine saliva in Leishmania infections. A bibliographic search was carried out in PubMed, SciELO and LILACS databases. The articles listed address the following aspects of the vector's saliva: intensification of infection; suppression and modulation of the host immune system; chemotaxis on phagocytic cells; induction of innate and adaptive immunity; isolation and characterization of immunoactive molecules and their possible protective function against Leishmaniasis.

Keywords: Lutzomyia; Phlebotomus; protection; sandflies, saliva.

\section{Efeitos imunomoduladores da saliva de flebotomínio na infecção por Leishmania: Revisão}

Resumo. A reconhecida ação de algumas proteínas presentes na saliva dos vetores flebotomíneos da Leishmaniose, como moduladores das respostas hemostáticas, inflamatórias e imunes durante a colonização do protozoário no organismo hospedeiro, criou a expectativa de formular uma vacina contra essa doença. O presente estudo teve como objetivo fornecer uma visão geral sobre pesquisas que abordam o papel da saliva de flebotomíneos em infecções por Leishmania. Foi realizada uma pesquisa bibliográfica nas bases de dados PubMed, SciELO e LILACS. Os artigos listados abordam os seguintes aspectos da saliva do vetor: intensificação da infecção; supressão e modulação do sistema imune do hospedeiro; quimiotaxia em células fagociticas; indução da imunidade inata e adaptativa; isolamento e caracterização de moléculas imunoativas e sua possível função protetora contra a leishmaniose.

Palavras-chave: Flebótomos; Lutzomyia; Phlebotomus; proteção; saliva.

$\pi$ eishmaniasis, an infection caused by protozoa of the genus Leishmania, family Trypanosomatidae and order Kinetoplastida is a zoonotic disease with several clinical manifestations that depend on both the parasite species and the host immune response (VAN Der Auwera \& DuJardin 2015). This disease is transmitted by dipterans of the subfamily Phlebotominae of the genera Lutzomyia and Phlebotomus, found in the New and Old World, respectively (Yong \& Duncan 1994; GaZZINELLI \& DENKERS 2006).

There are somelimiting aspects in the treatment of Leishmaniasis, such as its high cost, the difficulty of administration of the drugs (which drugs are usually administrated by endovenous or intramuscularly), long treatment period and drug toxicity. There is also a lack of response to antimonials, the first choice drug for treatment, characterizing resistant forms of the disease (DE PAULA et al. 2003).

The difficulties in controlling the disease have boosted studies in the last decades in an effort to uncover mechanisms of infection of Leishmaniasis in order to develop immunization methods and efficient treatments. In this sense, an important role of the phlebotomine vector's saliva was observed in order for Leishmania to be successfully established in the host organism (Trtus et al. 1988). Studies indicate that some proteins present in the vector's saliva may induce a protective immunological profile in the host when it is challenged. This immunomodulatory process could be capable of hindering the initial infection of Leishmania promastigotes in the target cell, creating the expectation of formulating a vaccine against Leishmaniasis (ENSERINK 2001; OlIVEIRA et al. 2015). In this sense, the objective of this manuscript is to discuss representative studies on the biological properties of sandfly salivary molecules in Leishmania infection, highlighting their biotechnological interest.

\section{GENERAL ASPECTS OF THE IMMUNOLOGICAL RESPONSE UPON LEISHMANIA INFECTION}

From the inoculation of the promastigote forms and saliva during the blood meal, a complex interaction between the parasite and the host's immune response begins, where they are internalized giving rise to phagosomes which fuses to the lysosomes forming a cellular compartment rich in proteolytic enzymes with digestive and microbicidal functions (RItTIG \& Bogdan 2000; Semini
Edited by:

Jeronimo Augusto Alencar

Article History:

Received: 13. iii.2018

Accepted: 3o.vii.2018
Corresponding author:

Ivan Brito Feitosa

\} ivan.feitosa@fiocruz.br

( ) No ORCID record
Funding agencies:

$\Delta$ Without funding declared 
et al. 2017). The vector's saliva induces cellular recruitment, influences the modulation of the T lymphocyte population, and inhibits the complement system and phagocytic cells, such as dendritic cells and neutrophils, as well as the appearance of late hypersensitivity reaction to saliva antigens and presence of IFN- $\gamma$ at the site of the sting (ANDRADE et al. 2005; VINHAS et al. 2007).

Initially, the presence of inoculated sentinel cells elicits a nonspecific acute inflammatory response in which they participate in pathogen-associated molecular patterns (PAMPs) and Toll-Like Receptors (TLR) rapidly leading to the activation of transcription factors in the hyaloplasm (GAzzinelui \& Denkers 2006). Once activated, the TLR signal through the formation of a TLR2$\mathrm{PI} 3 \mathrm{~K}$-phospholipase $\mathrm{C}$ complex (PLC) which induces activation of cytoplasmic phospholipase $\mathrm{A}_{2}$ and Cyclooxygenase-2, which are essential for the formation of prostaglandins (PGE2) (BHATTACHRJEe et al. 2016).

In this context, the analyze of eicosanoids, in $\mathrm{C} 57 \mathrm{BL} / 6$ mice measured ex vivo from leukocytes harvested by peritoneal cavity washing, induced by Lutzomyia longipalpis (Lutz \& Neiva) saliva, main vector of American visceral leishmaniasis (AVL), suggests a regulation in the early stages of Leishmania. infantum infection leading to implications in the interaction between PGE2 and Leukotrienes B4 (LTB4) on immunopathogenesis (ARAÚJO et al. 2014). These mediators involved in different mechanisms, where PGE2 suppresses the host immune response through inhibition in the production of proinflammatory cytokines, for example: IFN- $\gamma$, TNF- $\alpha$, IL-2 and IL-1 $\beta$ (HARRIs et al. 2002). While LTB4 plays a role in increasing proinflammatory cytokines, as well as a decreasing the infection in several pathologies, since nitric oxide production may increase (PETERS-GOLDEN et al. 2005; ROGERIO \& ANIBAL 2012).

In addition to these inflammatory inducers, the components of the complement system represent the first line of immune defense against Leishmania. The initial events of complement activation (fragments $\mathrm{C}_{3} \mathrm{a}, \mathrm{C}_{4} \mathrm{a}$ and $\mathrm{C}_{5} \mathrm{a}$ ) act as potent chemotactic stimuli for neutrophils, in addition to activating histamine-producing (vasodilator) mast cells, cytokines and other proinflammatory substances (Delves \& RoITt 2000). Despite these obstacles, it is known that metacyclic promastigote forms express a large amount of kinases that phosphorylate several proteins of the host's complement system ( $\mathrm{C}_{3}, \mathrm{C}_{5}$ and $\mathrm{C9}$ ), which can inactivate it, thus increasing its survival inside macrophages by promoting low oxidative metabolism (Hermoso et al. 1991). Recent studies have identified a protein present in sandfly saliva called SALO which specifically inhibited the classical pathway of the human complement system by a mechanism that appears to act on $\mathrm{C} 1 \mathrm{q}$ through the displacement of serine proteases from the $\mathrm{C} 1$ complex without inhibiting the binding of $\mathrm{C} 1 \mathrm{q}$ to $\mathrm{IgG}$ (FERREIRA et al. 2016). This synergistic action of proteins from the promastigote forms and saliva components may protect the parasite from mediated lysis during the initial stage of infection. Another study found that increased serine peptidase (ISP2) inhibitor in Le. donovani infected macrophages, etiologic agent of visceral leishmaniasis of the Old World, plays a critical role in the reduction of MASP2 via lectin, decreasing the formation of $\mathrm{C}_{3}$ and $\mathrm{C}_{5} \mathrm{c}$ and the membrane attack complex (Verma et al. 2018).

In this environment, the development of a cellular response is of great importance in the control of Leishmaniasis, macrophages, Langerhans cells, Th1-type CD4+ cells and the cytokines they release like IFN- $\gamma$, IL-12 and TNF- $\alpha$, are crucial in long-term resolution and protection against disease (Gomes et al. 2012). Once the Th2 lymphocyte response occurs, which is characterized by the intense release of IL-4, IL-5 and IL-10 cytokines, the host's initial inflammatory response is modified to a phenotype that is permissive to the infection. Connected to this phenomenon, higher levels of TGF- $\beta$ and prostaglandin $\mathrm{E}_{2}$ cytokines are able to inhibit IFN- $\gamma$ production and deactivate macrophages (MonTEIRo et al. 2007).

Even with a Th1 effector host immune response, Leishmania is able to silence mechanisms of NO (nitric oxide) and reactive oxygen species, such as hydrogen peroxide, synthesis, which are potent microbicides produced by macrophages (GREEN \& NACY 1993). For example, inhibition by membrane lipophosphoglycans (LPG) of promastigote forms acting on inducers of NO synthesis, such as PKC (protein kinase C), leads to a decrease in these potent effector molecules against the parasites (DEscoteaux \& TuRco 1993). This delay in NO production can also occur through mechanisms provoked by synthesized TGF- $\beta$ mainly $\mathrm{CD} 4+\mathrm{CD} 25+\mathrm{T}$ cells in individuals infected with Leishmania sp. leading to deleterious effects by increasing vulnerability (KARIMINIA et al. 2005).

Other mechanisms related to the evasion of Leishmania have been described; among these, the immunomodulatory effects due to salivary gland lysate (SGL) of $L$. longipalpis where an increase in IL-10 was observed stands out; similar to the SGL of Phlebotomus papatasi Scopoli, vector of Leishmania major L. the etiologic agent of zoonotic cutaneous leishmaniasis (ZCL), where IL-4 levels increased and IFN- $\gamma$, IL-12 and nitric oxide synthetase (iNOS) decreased with consequent worsening of saliva-induced skin lesions (Norsworthy et al. 2004).

\section{THE ROLE OF SOME SALIVARY COMPONENTS IN BLOOD-FEEDING AND HOST IMMUNITY}

Among the salivary properties of phlebotomines, the following stand out: the anticoagulant, vasodilator and antiplatelet factor, favoring the flow of blood and interstitial lymph for their feeding (ABDELADHIM et al. 2014). In addition to factors inherent to the host and the parasite, it has been demonstrated that some components of the insect's saliva also interfere in the host's immune response, favoring the persistence of the parasite in the macrophage, acting as one of the determinants of infection evolution (OliveIra et al. 2013).

The salive of L. longipalpis's saliva contains a potent vasodilator, maxadilan. This molecule is responsible for erythema caused by the bite during hematophagy inducing leukocyte chemotaxis and plasma extravasation in post-capillary venules through a mechanism associated with the type I polypeptide receptor of the pituitary adenylate cyclase activating peptide (PAC1) and C-X-C chemokine receptor type 1 (CXCR1) (LERNER et al. 1991; SvENSJO et al. 2011). In addition, the maxadilan, it has been shown to possess immunomodulatory characteristics with the elevation of intracellular macrophage cAMP, in order to reduce TNF- $\alpha$ production and increase IL-6 production (SOAREs et al. 1998).

Analyzing the salivary gland of the $P h$. arabicus transcriptome, which was recently shown to transmit Leishmania tropica, the causative agent of cutaneous leishmaniasis, four hyaluronidase coding sequences were identified (Hostomské et al. 2009). This enzyme hydrolyzes hyaluronic acid and chondroitin sulfate, important polymersin the constitution of animal connectivetissue whose function is to open the way for other glandular components that diffuse through the adjacent cutaneous tissue. This process seems to aid in the diffusion of the anti-hemostatic agents in the tissue and to guarantee the establishment of microhemorrhaging caused by the bite, causing these telmophagous insects to better explore their blood supply (Ribeiro et al. 2000). Similarly upon analysis, adenosine (ADO) and AMP present in Ph. papatasi saliva seem to utilize modulatory mechanisms through the A2a adenosine receptor (A2aR) to initiate the production of PGE2 and IL-10. Similarly, they may act in a paracrine manner since they induce regulatory $\mathrm{T}$ cells from effector $\mathrm{T}$ cells populations, implying a role in immunosuppression and establishment of the infection (CARREGARO et al. 2015). 
SANDFLY SALIVA EFFECTS IN AN EXPERIMENTAL INFECTION BY LEISHMANIA

The immune system responses to the salivary effects of sandflies on hosts are complex, specific, and depend on both the phlebotomine species and the Leishmania species. The induction of $L$. longipalpis saliva, for example, in mice inoculated with parasites, had less marked parasitism and less infiltration of macrophages at the inoculation site, accompanied by lower production of IL-4 and IL-10 and higher levels of IL-12 (LAURENTI et al. 2009).

Antagonistic results for Th2 and also Th1 immune responses were found by Menezes et al. (2008), who demonstrated a reduction in IL-10 production in monocytes that was not stimulated by saliva, but rather by LPS; and that infection with Le. braziliensis, stimulated by LPS, led to a significant increase in the production of TNF- $\alpha$, IL- 6 and IL-8. The effects exerted by the saliva of $L$. intermedia in human monocytes were different from those with L. longipalpis saliva (CostA et al. 2004) and Ph. papatasi saliva (Rogers \& Titus 2003); these differences may play an essential role in leishmaniasis.

The studies by Cavalcante et al. (2003) and Costa et al. (2004) demonstrated the interference of $L$. longipalpis salivary gland extracts in the complement cascade. The saliva acted on the classical route and the alternative route. They also found that the inactivation is not related to the inhibition of serine proteases from the complement system. The saliva of L. longipalpis also affected the expression of costimulatory molecules on the surface of monocytes, macrophages and human dendritic cells. Exposure of monocytes and macrophages to saliva extracts resulted in decreased CD80 expression and increased HLA-DR, whereas CD86 was increased only in monocytes and remained unchanged in macrophages.

After the evaluation of maxadilan on the secretion of cytokines and NO on the survival of Le. major through stimulation in macrophages in mice with LPS, not only the increase in the response of type 2 cytokine (IL-10), but also a decrease in type 1 cytokines (IL-12p70 and TNF- $\alpha$ ) and NO was observed (BRODIE et al. 2007). A subsequent study analyzed that dendritic cells of mice, when exposed to maxadilan, presented altered levels of the co-stimulatory molecules CD80 and CD86. In addition to increased secretion of type 2 cytokine (IL-10) and decreased secretion of type 1 cytokines (TNF- $\alpha$, IL-12p40, and IFN- $\gamma$ ), this exposure to maxadilan consistently reduced the extent of dendritic cell-induced CD4+ T cell proliferation and boosted the targeting for a Th2 response (WHEAT et al. 2008).

It has been shown that the salivary gland lysate of $L$. longipalpis may be a facilitator in Leishmania infection, while modulating leukocyte recruitment and Th2 cytokine production in the inflammatory focus (MonTEIRo et al. 2007). However, in the species $L$. intermedia pre-exposure to saliva did not result in effective protection against Le. braziliensis infection. Mice immunized with saliva extract when inoculated with parasites and saliva showed continuous multiplication of parasites and a low proportion between IFN- $\gamma$ and IL-4 levels (Moura et al. 2007).

In order to reproduce the seasonality of host-vector interaction in nature, RoHoušová et al. (2011) exposed mice to Ph. duboscqi bites for long and short term periods and inoculated Le. major soon thereafter or after a period with no sandfly bites. Only animals exposed to short-term bites and inoculated with parasites and saliva extract soon after sensitization developed protection against infection, as demonstrated previously by KAMHAw et al. (2000). They then suggested that the results obtained may explain the persistence of Leishmaniasis in endemic areas.
Based on the frequent exposure of individuals from endemic areas, the study done by Mukbel et al. (2016) investigated the human immune response in endemic areas of $P h$. papatasi in volunteers exposed to frequent bites. It was found that the most reactive salivary proteins for the production of antibodies are $\mathrm{SP}_{28}, \mathrm{SP}_{32}$ and $\mathrm{SP}_{3} 6$. To date, it is known that the main reactive humoral salivary proteins are: $\mathrm{SP}_{2} 8, \mathrm{SP}_{32}, \mathrm{SP}_{36}, \mathrm{SP} 42$ and SP32, among them the immunodominant SP28, SP32 and SP36 (ABDELAdHim et al. 2011).

In mice deficient in B lymphocytes, immunized with the SP15 plasmid vaccine, Le. major infection was successfully controlled (VAlenzuela et al. 2001). Based on this, it was suggested that the salivary protein $\mathrm{PpSP} 15$ from $P h$. papatasi as well as $P h$. dubosqui would be the best mediator of immune cell activation and, thus, a promising candidate for the development of a future vaccine (ElnAiEm et al. 2005; LeSTINOva et al. 2015).

Analyses in dogs also detected a strong immune response to two vector salivary proteins. In a delayed-type hypersensitivity (DTH) test performed with 35 salivary proteins from L. longipalpis, it was found that the proteins LJL143 and LJM17 elicited the most intense responses, comparable to that of the whole saliva extract. The adaptive immune response was evidenced by the dominance of IgG2 antibodies and substantial production of IFN- $\gamma$ by $\mathrm{CD}_{3}{ }^{+} \mathrm{CD} 4^{+} \mathrm{T}$ cells stimulated with recombinant proteins or saliva extract. In vitro, macrophages infected with Le. infantum efficiently killed parasites after the addition of autologous $\mathrm{T}$ cells from dogs immunized with LJL143 and LJM17 and stimulated with saliva, showing a marked reduction in infection in macrophages (Collin et al. 2009).

In hamsters, immunization promoted by vaccines of plasmids coding for LJM19 (salivary antigen) and KMP11 (Leishmania antigen) were evaluated. Animals immunized and infected with Le. infantum maintained a normal hematological profile even five months after infection, whereas unimmunized hamsters showed significant anemia (Silva et al. 2011).

Specific markers of mosquito exposure were found to be exclusive to L. longipalpis saliva. Among nine proteins tested, in the study by TeIXEIRA et al. (2010), LJM17 was the only one recognized by the serum of three different hosts (humans, dogs and foxes); LJM11 was recognized by human and dog serum. They determined, through reactive intensity, that LJM17 and LJM11 are specifically recognized by the serum of humans inhabiting endemic areas for VL transmitted by L. longipalpis. $\mathrm{XU}$ et al. (2011) report that in mice, LJM11 confers protective immunity against Le. major infection and add that splenocytes from mice sensitized with $L$. longipalpis bites produced IFN- $\gamma$ under LJM11 stimulus, demonstrating the induction of a Th1based immunospecific systemic response. Recents work's confirm the immunomodulatory role of Phlebotomium saliva, such as, improving the function of anti-leishmania macrophages with the production of nitric oxide (NO), tested in rabbits (Pushranjali et al. 2016), Immunity to the sand fly salivary protein SALO protected hamsters against Leishmania infantum and Le braziliensis infection and, more recently, a vaccine combination of a genetically modified Leishmania with SALO conferred strong protection against Le. donovani infection (AsoJo et al. 2017).

Studies on the salivary effects of sandflies reflect the importance of research to understand the challenge posed by Leishmaniasis. The advances have not yet been able to meet the real needs of the immense population exposed to the risk of the disease. Despite the withdrawn diversification over the last years, most published articles restrict their investigation to the relationship of the saliva of two species, L. longipalpis and Ph. papatasi, on infection by one parasite, Le. major. This concentration in the scientific production contrasts with the amplitude of relations undertaken by the various vectors in the infection of the most 
diverse types of Leishmania. We suggest that the wealth of information already described by other specific studies on these species or that the fact that these relationships already have a certain degree of understanding further drive the search for data in this way.

These reports consolidate knowledge about the salivary properties of sandflies in the intensification of Leishmania infection. From this, it is more evident that the same biochemical and pharmacological diversity of the salivary apparatus capable of favoring the parasite may be useful for the development of protective mechanisms for the hosts. The intense immunomodulatory activity of some compounds has been identified with the intention of reversing this role and stimulating an effective defense against the disease.

\section{FINAL CONSIDERATIONS}

The present review demonstrated that, according with the literature, the vector-host relationship is not limited to the simple inoculation of the parasite in the organism and that the influence determined by the insect on the induction of responses by the host is important in the dynamics of the disease and has been intensively investigated. Adding knowledge to the mechanism of triggering the initial immune response of the host organism is of fundamental importance, considering that this phase is decisive for the progression of the infection. However, managing variables from at least three different interrelated organisms evidencing processes with varying degrees of dependence is a major challenge. Advances in the development of vaccines for humans, and especially for dogs, are extremely important. In view of the fact that in many countries euthanasia of infected animals is still advocated. Therefore, an effective and low-cost vaccine as a control measure for visceral leishmaniasis would bring benefits, especially for dogs from endemic areas in low-income regions.

\section{REFERENCES}

Abdeladhim, M., A.M. Ben, S. Marzouki, H.N. Belhadj, T. Boussoffara, A.N. Belhaj, S.A. Ben \& H. Louzir H. 2011. Human cellular immune response to the saliva of Phlebotomus papatasi is mediated by IL-10-producing CD8+ T cells and Th1- polarized CD4+ lymphocytes. PLoS Neglected Tropical Diseases, 5: e1345. DOI: https://doi.org/10.1371/journal. pntd.0001345.

Abdeladhim, M., Kamhawi S., \& J.G. Valenzuela, 2014. What's behind a sand fly bite? The profound effect of sand fly saliva on host hemostasis, inflammation and immunity. Infection, genetics and evolution : Journal of Molecular Epidemiology and Evolutionary Genetics in Infectious Diseases. 28:691703. DOI: https://doi.org/10.1016/j.meegid.2014.07.028.

Andrade, B.B., C.R. Teixeira, A. Barral \& M. Barral-Netto, 2005. Haematophagous arthropod saliva and host defense system: a tale of tear and blood. Anais da Academia Brasileira de Ciências, 77: 665-693. DOI: https://doi.org/10.1590/s000137652005000400008 .

Araújo, T.S., D.B. Prates, J. França-Costa, N.F. Luz, B.B. Andrade, J.C. Miranda, C.L. Brodskyn, A. Barral, P.T. Bozza \& V.M. Borges, 2014. Prostaglandin E2/Leukotriene B4 balance induced by Lutzomyia longipalpis saliva favors Leishmania infantum infection. Parasites \& Vectors. 7: 601. DOI: https://doi.org/10.1186/s13071-014-0601-8.

Asojo, O.A., A. Kelleher, Z. Liu, J. Pollet, E.M. Hudspeth, W.C. Rezende, M.J. Groen, C.A. Seid, M. Abdladhim, S. Townsend, W. De Castro, A. Mendes-Sousa, D.C. Bartholomeu, R.T. Fujiwara, M.E. Bottazzi, P.J. Hotez, B. Zhan, F. Oliveira, S. Kamhawi \& J.G. Valenzuela, 2017. Structure of SALO, a leishmaniasis vaccine candidate from the sand fly Lutzomya longipalpis. PLoS Neglected Tropical Diseases, 11: eoo05374. DOI: https://doi.org/10.1371/journal.pntd.0005374.

Bhattacharya, P., S. Ghosh \& S.A. Ejazi, 2016. Induction of IL10 and TGF $\beta$ from $\mathrm{CD}_{4}+\mathrm{CD}_{2} 5+\mathrm{FoxP}_{3}+\mathrm{T}$ Cells Correlates with Parasite Load in Indian Kala-azar Patients Infected with Leishmania donovani. Bates PA, ed. PLoS Neglected Tropical Diseases, 10: eoo04422. DOI: https://doi.org/10.1371/ journal.pntd.0004422.

Bhattachrjee, A., S. Majumder, S. Das \& S. Ghosh, 2016. Leishmania donovani induced PGE2 generation is critically dependent on host TLR2-cPLA2 signaling. Infection and Immunity. 84 : 2963-2973. DOI: https://doi.org/10.1128/ iai.00528-16.

Brodie, T.M., M.C. Smith, R.V. Morris, \& R.G. Titus, 2007. Immunomodulatory effects of the Lutzomyia longipalpis salivary gland protein maxadilan on mouse macrophages. Infection and Immunity, 75: 2359-2365, DOI: https://doi.org/10.1128/iai.01812-06.

Carregaro, V., J.M. Ribeiro, J.G. Valenzuela, D.L. Souza-Júnior, D.L. Costa, C.J. Oliveira, L.A. Sacramento, M.S. Nascimento, C.M. Milanezi, F.Q. Cunha \& J.S. Silva, 2015. Present on Phlebotomine Saliva Induce Immunossuppression and Promote the Infection Establishment. PLoS Neglected Tropical Diseases, 9: eooo3600. DOI: https://doi.org/10.1371/journal.pntd.0003600.

Cavalcante, R.R., M.H. Pereira \& N.F. Gontijo, 2003. Anticomplement activity in the saliva of phlebotomine sand flies and other haematophagous insects. Parasitology, 127: 87-93. DOI: https://doi.org/10.1017/s0031182003003329.

Collin, N., R. Gomes, C. Teixeira, L. Cheng, A. Laughinghouse, J.M. Ward, D.E. Elnaiem, L. Fischer, J.G. Valenzuela \& S. Kamhawi 2009. Sand fly salivary proteins induce strong cellular immunity in a natural reservoir of visceral leishmaniasis with adverse consequences for Leishmania. PLoS Pathogens. 5: e1000441. DOI: https://doi.org/10.1371/ journal.ppat.1000441.

Costa, D.J., C. Favali , J. Clarencio, L. Afonso, V. Conceicao, J.C. Miranda, R.G. Titus, J. Valenzuela, M. Barral-Netto, A.Barral \& C.I. Brodskyn, 2004. Lutzomyia longipalpis salivary gland homogenate impairs cytokine production and costimulatory molecule expression on human monocytes and dendritic cells. Infection and Immunity, 72: 1298-1305. DOI: https://doi.org/10.1128/iai.72.3.1298-1305.2004.

De Paula, C.D.R., J.H.D. Sampaio, D.R. Cardoso \& R.N.R. Sampaio, 2003. Estudo comparativo da eficácia de isotionato de pentamidina administrada em três doses durante uma semana e de $\mathrm{N}$-metil-glucamina $20 \mathrm{mg} \mathrm{SbV} / \mathrm{kg} /$ dia durante 20 dias para o tratamento da forma cutânea da leishmaniose tegumentar americana. Revista da Sociedade Brasileira de Medicina Tropical, 36: 365-371.

Delves, P.J. \& I.M. Roitt, 2000. The immune system. First of two parts. New England Journal of Medicine, 343: 37-49. DOI: https://doi.org/10.1056/nejm200007063430107.

Descoteaux, A. \& S.J. Turco, 1993. The lipophosphoglycan of Leishmania and macrophage protein kinase C. Parasitology Today, 9: 468-471. DOI: https://doi.org/10.1016/01694758(93)90105-0.

Elnaiem, D.-E.A., C. Meneses, M. Slotman \& G. Lanzaro, C. 2005. Genetic variation in the sand fly salivary protein, SP-15, a potential vaccine candidate against Leishmania major. Insect Molecular Biology, 14: 145-150. DOI: https://doi.org/10.1111/j.1365-2583.2004.00539.x.

Enserink, M., 2001. Infecton Sand fly saliva may be key to new vaccine. Science. 293: $1028^{\mathrm{a}}-1028$. DOI: https://doi.org/10.1126/science.293.5532.1028a.

Ferreira, V.P., V. Fazito Vale, M.K. Pangburn, M. Abdeladhim, A.F. Mendes-Sousa, I.V. Coutinho-Abreu, M. Rasouli, E.A. Brandt, C. Meneses, K.F. Lima, R. Nascimento Araújo, M.H. Pereira, M. Kotsyfakis, F. Oliveira, S. Kamhawi, J.M. Ribeiro, N.F. Gontijo, N. Collin, \& J.G. Valenzuela, 2016. SALO, a novel classical pathway complement inhibitor from saliva of the sand fly Lutzomyia longipalpis. Scientific Reports. 6: 19300. DOI: https://doi.org/10.1038/srep19300.

Gazzinelli, R.T. \& E.Y. Denkerst, 2006. Protozoan encounters with toll-like receptor signalling pathways: implications for 
host parasitism. Nature Reviews Immunology, 6: 895-906. DOI: https://doi.org/10.1038/nri1978.

Gomes, R., F. Oliveira, C. Teixeira, C. Meneses, D.C. Gilmore, D.E. Elnaiem, S. Kamhawi \& J.G. Valenzuela. 2012. Immunity to sand fly salivary protein LJM11 modulates host response to vector-transmitted Leishmania conferring ulcer-free protection. Journal of Investigative Dermatology, 132: 27352743. DOI: https://doi.org/10.1038/jid.2012.205.

Green, S.J. \& C.A. Nacy, 1993. Antimicrobial and immunopathologic effects of cytokine-induced nitric oxide synthesis. Current Opinion in Infectious Diseases, 6: 384396.

Harris, S.G., J. Padilla, L. Koumas, D. Ray \& R.P. Phipps, 2002. Prostaglandins as modulators of immunity. Trends in Immunology 23: 144-150. DOI: https://doi.org/10.1016/ s1471-4906(01)02154-8.

Hermoso, T., Z. Fishelson, S.L. Becker, K. Hirscheberg \& C.L. Jaffe, 1991. Leishmanial protein kinases phosphorylate components of the complement cascade. EMBO Journal, 10: 4061-4067. DOI: https://doi.org/10.1002/j.1460-2075.1991. tb04982.x.

Hostomská, J., V. Volfová, J. Mu, M. Garfield, I. Rohoušová, P. Volf, J.G. Valenzuela \& R.C. Jochim 2009. Analysis of salivary transcripts and antigens of the sand fly Nucleosides Phlebotomus arabicus. BMC Genomics. 10: 282. DOI: https:// doi.org/10.1186/1471-2164-10-282.

Hostomska J., I. Rohousova, V. Volfova, D. Stanneck, N. Mencke \& P. Volf. 2008. Kinetics of canine antibody response to saliva of the sand fly Lutzomyia longipalpis. Vector-Borne and Zoonotic Diseases. 8: 443-450. DOI: https://doi.org/10.1089/vbz.2007.0214.

Kamhawi, S., Y. Belkaid, G. Modi, E. Rowton \& D. Sacks, 2000. Protection against cutaneous leishmaniasis resulting from bites of uninfected sand flies. Science. 290: 1351-1354. DOI: https://doi.org/10.1126/science.290.5495.1351.

Kariminia, A., E. Bourreau, H. Pascalis, P. Couppie, D. SainteMarie, F. Tacchini-Cottier \& P. Launois 2005. Transforming growth factor beta 1 production by $\mathrm{CD} 4(+) \mathrm{CD} 25(+)$ regulatory $\mathrm{T}$ cells in peripheral blood mononuclear cells from healthy subjects stimulated with Leishmania guyanensis. Infection and Immunity, 73: 5908-5914. DOI: https://doi.org/10.1128/ iai.73.9.5908-5914.2005.

Laurenti, M.D., V.L.R. Matta, T. Pernichelli, N.F.C. Secundino, L.C. Pinto, C.E.P. Corbett \& P.P.F. Pimenta, 2009. Effects of salivary gland homogenate from wild-caught and laboratory-reared Lutzomyia longipalpis on the evolution and immunomodulation of Leishmania (Leishmania) amazonensis infection. Scandinavian Journal of Immunology. 70: 389-95. DOI: https://doi.org/10.1111/ j.1365-3083.2009.02310.x.

Lerner, E.A., Ribeiro, J.M., Nelson, R.J. \& M.R. Lerner, 1991. Isolation of maxadilan, a potent vasodilatory peptide from the salivary glands of the sand fly Lutzomyia longipalpis. Journal of Biological Chemistry. 266: 11234-11236.

Lestinova, T., M. Vlkova, J. Votypka, P. Volf \& I. Rohousova, 2015. Phlebotomus papatasi exposure cross-protects mice against Leishmania major co-inoculated with Phlebotomus duboscqi salivary gland homogenate. Acta Tropica, 144: 9-18. DOI: https://doi.org/10.1016/j.actatropica.2015.01.005.

Menezes, M., D.J. Costa, J. Clarêncio, J. Miranda, A. Barral, M. Barral-Netto, C. Brodskyn \& C.I. Oliveira, 2008. Immunomodulation of human monocytes following exposure to Lutzomyia intermedia saliva. BMC Immunology, 9:1-12. DOI: https://doi.org/10.1186/1471-2172-9-12.

Monteiro, M. C., H.C. Lima, A.A.A. Souza, R.G. Titus, P.R.T. Romão \& F.Q. Cunha, 2007. Effect of Lutzomyia longipalpis salivary gland extracts on leukocytes migration induced by Leishmania major. American Journal of Tropical Medicine and Hygiene, 76: 88-94. Doi: https://doi.org/10.4269/ ajtmh.2007.76.88.
Moura, T.R., F. Oliveira, F.O. Novais, J.C. Miranda, J. Clarêncio, I. Follador, E.M. Carvalho, J.G. Valenzuela, M. Barral-Netto, A.Barral, C. Brodskyn \& C.I. Oliveira, 2007. Enhanced Leishmania braziliensis infection following pre-exposure to sandfly saliva. PLoS Neglected Tropical Diseases, v: e84. DOI: https://doi.org/10.1371/journal.pntd.0000084.

Mukbel, R.M., R.H. Khasharmeh, N.S. Hijjawi, M.S. Khalifeh, M.M. Hatmal \& M.A. McDowell. 2016. Human immune response to salivary proteins of wild-caught Phlebotomus papatasi. Parasitology Research, 115: 3345-3355. DOI https://doi.org/10.1007/s00436-016-5094-2.

Norsworthy, N. B., J. Sun, D. Elnaiem, G. Lanzaro \& L. Soong, 2004. Sand Fly Saliva Enhances Leishmania amazonensis Infection by Modulating Interleukin-10 Production. Infection and Immunity, 72: 1240-1247. DOI: https://doi.org/10.1128/ iai.72.3.1240-1247.2004.

Oliveira, F., Rowton, E., H. Aslan, R. Gomes, P.A. Castrovinci, P.H. Alvarenga, M. Abdeladhim, C. Teixeira, C. Meneses, L.T. Kleeman, A.B. Guimaraes-Costa, T.E. Rowland, D. Gilmore, S. Doumbia, S.G. Reed, P.G. Lawyer, J.F. Andersen, S. Kamhawi \& J.G. Valenzuela, 2015. A sand fly salivary protein vaccine shows efficacy against vector-transmitted cutaneous leishmaniasis in nonhuman primates. Science Translational Medicine, 7: 290ra9o. DOI: https://doi.org/10.1126/ scitranslmed.aaa3043.

Oliveira, F., B. Traoré, R. Gomes, O. Faye, D.C., Gilmore, S. Keita, P. Traoré, C. Teixeira, C. A. Coulibaly, S. Samake, C. Meneses, I. Sissoko, R. M. Fairhurst, M.P. Fay, J.M. Anderson, S. Doumbia, S. Kamhawi \& J.G. Valenzuela, 2013. Delayedtype hypersensitivity to sand fly saliva in humans from a leishmaniasis-endemic area of Mali is TH1-mediated and persists to midlife. Journal of Investigative Dermatology, 133, 452-459. DOI: https://doi.org/10.1038/jid.2012.315.

Peters-Golden, M., C. Canetti, P. Mancuso, M.J. Coffey, 2005. Leukotrienes: underappreciated mediators of innate immune responses. Journal of Immunology,174: 589-594. DOI: https://doi.org/10.4049/jimmunol.174.2.589.

Pushpanjali, A.K.T., B. Purkait, F. Jamal, M.K. Singh, G. Ahmed, S. Bimal, V. Kumar, S.K. Singh, S. Keshri, P. Das \& S. Narayan, 2016. Direct evidence for role of antisaliva antibodies against salivary gland homogenate of $\mathrm{P}$. argentipes in modulation of protective Th1-immune response against Leishmania donavani. Cytokine. 86: 79-85. DOI: https://doi.org/10.1016/j.cyto.2016.07.017.

Ribeiro, J., R. Charlab, E. Rowton \& E. Cupp, 2000. Simulium vittatum (Diptera: Simuliidae) and Lutzomyia longipalpis (Diptera: Psychodidae) salivary gland hyaluronidase activity. Journal Medical Entomology, 37: 743-747. DOI: https://doi.org/10.1603/0022-2585-37.5.743.

Rittig, M.G. \& R.G. Bogdan, 2000. Leishmania-Host-cell Interaction: Complexities and Alternative Views. Parasitology Today, 16: 292-297. DOI: https://doi.org/10.1016/s01694758(00)01692-6.

Rogerio,A.P.\&F.F.Anibal, 2012. Roleofleukotrienes on protozoan and helminth infections. Mediators of inflammation, 2012: 595694. DOI: https://doi.org/10.1155/2012/595694.

Rogers, K.A. \& R.G. Titus, 2003. Immunomodulatory effects of maxadilan and Phlebotomus papatasi sand fly salivary gland lysates on human primary in vitro immune responses. Parasite Immunology, 25: 127-134. DOI: https://doi.org/10.1046/j.1365-3024.2003.00623.x.

Rohoušová, I., J. Hostomska, M. Viková, T. Kobets, M. Lipoldová, P. Volf, 2011. The protective effect against Leishmania infection conferred by sand fly bites is limited to short-term exposure. International Journal for Parasitology, 41: 481485. DOI: https://doi.org/10.1016/j.ijpara.2011.01.003.

Semini, V., T. Aebischer, 2018 Phagosome proteomics to study Leishmania's intracellular niche in Macrophages. International Journal of Medical Microbiology, 308: 68-76. DOI: https://doi.org/10.1016/j.ijmm.2017.09.003. 
Silva, R.A.A., N.M. Tavares, D. Costa, M. Pitombo, L. Barbosa, K. Fukutani, J.C. Miranda, C.I. Oliveira, J.G. Valenzuela, A. Barral, M. Soto, M. Barral-Netto \& C. Brodskyn, 2011. DNA vaccination with KMP11 and Lutzomyia longipalpis salivary protein protects hamsters against visceral leishmaniasis. Acta Tropica, 120: 185-90. DOI: https://doi.org/10.1016/j. actatropica.2011.08.007.

Bozza, M, M.B.P. Soares, P.T. Bozza, A.R. Satoskar, T.G. Diacovo, F. Brombacher, R.G. Titus, C.B. Shoemaker \& J.R. David. 1998. The PACAP-type I receptor agonist maxadilan from sand fly saliva protects mice against lethal endotoxemia by a mechanism partially dependent on IL-10. European Journal of Immunology, 28: 3120-3127. DOI: https://doi. org/10.1002/(sici)1521-4141(199810)28:10\%3C3120::aidimmu3120\%3E3.0.c0;2-3.

Svensjo, E., E.M. Saraiva, R.S. Amendola, C. Barja-Fidalgo, M.T. Bozza, E.A. Lerner, M.M. Teixeira \& J. Scharfstein, 2012. Maxadilan, the Lutzomyia longipalpis vasodilator, drives plasma leakage via PAC1-CXCR1/2-pathway. Microvascular Research, 83 185-193. DOI: https://doi.org/10.1016/j. mvr.2011.10.003.

Teixeira, C., R. Gomes, N. Collin, D. Reynoso, R. Jochim, F. Oliveira, A. Seitz, D.E. Elnaiem, A. Caldas, A.P. de Souza, C.I. Brodskyn, C.I. de Oliveira, I. Mendonca, C.H. Costa, P. Volf, A. Barral, S. Kamhawi \& J.G. Valenzuela, 2010. Discovery of markers of exposure specific to bites of Lutzomyia longipalpis, the vector of Leishmania infantum chagasi in Latin America. PLoS Neglected Tropical Diseases, 4: e638. DOI: https://doi.org/10.1371/journal.pntd.oooo638.

Titus, R.G. \& J.M.C. Ribeiro, 1988. Salivary gland lysates from the sand fly Lutzomyia longipalpis enhance Leishmania infectivity. Science, 239: 1306-1308. DOI: https://doi.org/10.1126/science.3344436.

Valenzuela, J.G., Y. Belkaid, M.K. Garfield, S. Mendez, S. Kamhawi, E.D. Rowton, D.L. Sacks \& J.L Ribeiro, 2001. Toward a defined anti- Leishmania vaccine targeting vector antigens: characterization of a protective salivary protein. The Journal of Experimental Medicine, 194: 331-342. DOI: https://doi.org/10.1084/jem.194.3.331.
Van der Auwera, G. \& J.C. Dujardin, 2015. Species Typing in Dermal Leishmaniasis. Clinical Microbiology Reviews, 28: 265-294. DOI: https://doi.org/10.1128/cmr.00104-14.

Verma, S. A. Mandal, Md. Y. Ansari, A. Kumar, K. Abhishek, A.K. Ghosh, A. Kumar, V. Kumar, S. Das, P. Das, 2018. P.Leishmania donovani Inhibitor of Serine Peptidases 2 Mediated Inhibition of Lectin Pathway and Upregulation of C5aR Signaling Promote Parasite Survival inside Host. Frontiers in Immunology, 9: 63. DOI: https://doi. org/10.3389/fimmu.2018.00063.

Vinhas, V., B.B. Andrade, F. Paes, A. Bomura, J. Clarencio, J.C. Miranda, A. Báfica, A. Barral \& M. Barral-Netto, 2007. Human anti-saliva immune response following experimental exposure to the visceral leishmaniasis vector, Lutzomyia longipalpis. European Journal of Immunology, 37: 3111-3121. DOI: https://doi.org/10.1002/eji.200737431.

Wheat, W.H., K.E. Pauken, R.V. Morris, R.G. Titus, 2008. Lutzomyia longipalpis salivary peptide maxadilan alters murine dendritic cell expression of $\mathrm{CD} 80 / 86, \mathrm{CCR} 7$, and cytokine secretion and reprograms dendritic cell-mediated cytokine release from cultures containing allogeneic $\mathrm{T}$ cells. Journal of Immunology, 180: 8286-8298. DOI: https://doi.org/10.4049/jimmunol.180.12.8286.

XU, X., F. Oliveira, B.W. Chang, N. Collin, R. Gomes, C. Teixeira, D. Reynoso, V. My Pham, D.E. Elnaiem, S. Kamhawi, J.M. Ribeiro, J.G. Valenzuela \& J.F. Andersen, 2011. Structure and function of a "yellow" protein from saliva of the sand fly Lutzomyia longipalpis that confers protective immunity against Leishmania major infection. The Journal of Biological Chemistry, 286: 32383-32393. DOI: https://doi.org/10.1074/ jbc.m111.268904.

Young, D.G. \& M.A. Duncan, 1994. Guide to the identification and geographic distribution of Lutzomyia sandflies in Mexico, the West Indies, Central and South America (Diptera: Psychodidae). Defense Technical Information Center, 881p. DOI: https://doi.org/10.21236/ada285737.

\section{Suggestion citation:}

Feitosa, I.B, W.R. Aguida \& C.B.G. Teles, 2018. Immunomodulating effects of Phlebotomine saliva in Leishmania infection: Review. EntomoBrasilis, $11(3): 156-161$.

Available on: doi:10.12741/ebrasilis.v11i3.776
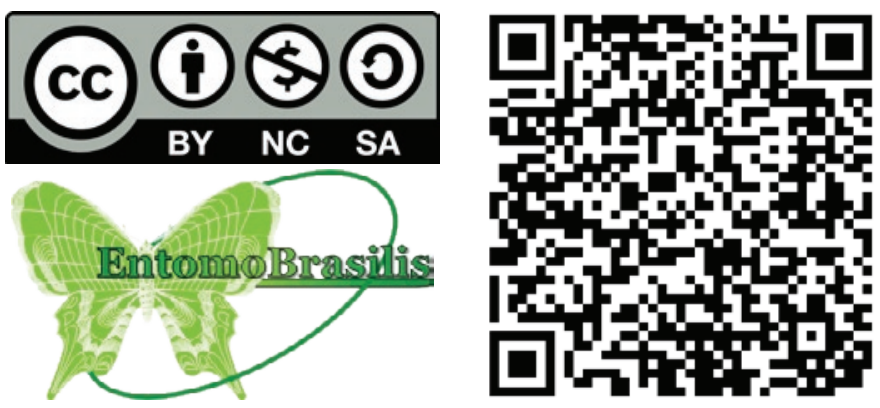